\title{
Evaluation of an indirect haemagglutination kit for the rapid serological diagnosis of Mycoplasma pneumoniae infections
}

\author{
P. TAYLOR
}

From the Department of Virology, Brompton Hospital, Fulham Road, London SW3 6HP, UK

SUMMARY A recently introduced indirect haemagglutination kit for the detection of Mycoplasma pneumoniae antibodies is compared with the standard method of complement fixation. It is concluded that the kit provides a rapid, simple, and moderately sensitive means of detecting antibodies and, in some cases, enables these to be detected in the early, acute stage of infection.

A complement fixation test (CF) is adopted by most laboratories for the routine serological diagnosis of Mycoplasma pineumoniae infections. The particular advantage of this test is that it may be combined with other CF tests for evidence of infection with respiratory viruses but, because an overnight complement fixation is normally used, the results cannot be assessed for 18 hours or more. More sensitive serological techniques include indirect immunofluorescence (Skaug et al., 1976), radioimmunoprecipitation, and complement-mediated killing (Brunner et al., 1973). These latter methods are technically demanding in both time and equipment and hence are restricted to specialised laboratories.

An indirect haemagglutination (IHa) test for $M$. pneumoniae antibody using tanned erythrocytes was first described by Dowdle and Robinson (1964) and has been modified by Lind (1968) and Ghyka et al. (1977). The IHa is both sensitive and specific, takes one hour to perform, and may detect antibody before other techniques will do so. It seems to have distinct advantages over other tests for rapid seroJogical diagnosis but the preparation and standardisation of tanned erythrocytes is technically laborious, thus limiting its routine use. Diamed Diagnostics have recently introduced a $M$. pneumoniae indirect haemagglutination kit (Fujizoki, Serodia-Myco) which utilises freeze-dried sensitised erythrocytes. This paper compares the new Fujizoki IHa kit with CF for the serological diagnosis of $M$. pneumoniae infections.

Received for publication 28 September 1978

\section{Material and methods}

TEST SERA

Sera were received in the Brompton Hospital virus laboratory for routine serological examination between August 1971 and March 1978; the majority were from patients diagnosed as 'pneumonia'. The patients were grouped as follows:

\section{Category I}

335 patients whose serum did not show a raised CF titre to $M$. pneumoniae in a single sample taken during the acute stage of pneumonia, although raised levels of antibody (1/160 or greater) were detected in some sera to one of the following agents: influenza $\mathbf{A}$ and $\mathbf{B}$, respiratory syncytial virus, adenovirus, Chlamydia psittaci, and Coxiella burneti.

\section{Category II}

108 patients whose serum showed a raised CF titre to $M$. pneumoniae (1/160 or greater) in a single sample taken during the acute stage of pneumonia, suggesting recent infection with $M$. pneumoniae.

\section{Category III}

23 patients whose paired sera (acute and convalescent) showed a fourfold or greater rise in CF titre to $M$. pneumoniae, thus indicating recent infection.

\section{TEST METHODS}

The CF test employed throughout was a microtitre adaptation of Bradstreet and Taylor's (1962) method using antigens supplied by the Standards Laboratory, Colindale. Microtitre plates with Ushaped wells together with microdiluters and micro- 
droppers (Gibco-Biocult Ltd, Paisley) were used for both the CF and IHa tests. The Fujizoki kit contains a phosphate buffered saline diluent which was used for reconstitution of both the lyophilised chicken erythrocytes (sensitised and unsensitised) and dilution of the test sera. Reagents and sera were allowed to reach ambient temperature before the test was started. Sera were not heat inactivated as with the CF test. All sera were initially examined at a dilution of $1 / 10$ as follows: $0.1 \mathrm{ml}$ of diluent was added to well $\mathrm{A}$ and $\mathbf{0 . 0 2 5} \mathrm{ml}$ to each of two adjacent wells B and C. A microdiluter was used to transfer $0.025 \mathrm{ml}$ of serum to well $\mathrm{A}$, which was rotated, and then $0.025 \mathrm{ml}$ of the mixture was transferred to well $B$ and rotated before being blotted dry and washed. A further 1/10 dilution was similarly prepared in well $\mathrm{C} ; 0.075 \mathrm{ml}$ of sensitised cells were added to well $\mathrm{B}$ and $0.075 \mathrm{ml}$ of unsensitised cells to well C. A positive control serum supplied with the kit was incorporated into each series of tests performed. Serial dilutions were performed on some sera by double diluting $0.025 \mathrm{ml}$ from well $A$ in $0.025 \mathrm{ml}$ of diluent contained in further wells D, E, F, etc. The plate was 'tapped' by hand to mix the cells and sera and covered to prevent evaporation; the cells were then allowed to settle at ambient temperature for between 50 and 60 minutes.

Agglutination patterns were considered reactive when a smooth lattice of cells, sometimes with its edges slightly folded, covered the base of the well. The manufacturers of this kit recommend that the final dilution of serum should be $1 / 40$ since 3 volumes of cells have been added to the $1 / 10$ dilution of serum. In this study a dilution of $1 / 10$ (the initial dilution of serum) has been used in order that a direct comparison can be made with the CF test which does not compensate for the addition of reagents. When agglutination was observed with unsensitised cells attempts were made to absorb the non-specific agglutination with packed adult chicken cells (Tissue Culture Services, Slough).

\section{Results}

A comparison of the CF and IHa titres on sera from patients in categories I and II is shown in Table 1. Of the 335 sera with CF titres below $1 / 160$, two with CF titres of $1 / 20$ and $1 / 40$ had IHa titres of $1 / 320$ and $1 / 20$ respectively. No significant CF titres to other respiratory pathogens were detected in these sera. The time of onset of symptoms was not known in these two patients. Sera with CF titres of $1 / 160$, $1 / 320$, and $1 / 640$ or more were positive by IHa in $48 \%, 67 \%$, and $86 \%$ of cases respectively. Nonspecific agglutination occurred in $3.2 \%(14 / 443)$ of sera in these groups. Such agglutination could not be absorbed by treatment with fresh chicken erythrocytes.

Table 1 Comparison of $C F$ and indirect haemagglutination tests on 443 single sera from patients with pneumonia

\begin{tabular}{|c|c|c|c|c|}
\hline \multirow{2}{*}{$\begin{array}{l}\text { No. } \\
\text { of sera } \\
\text { tested }\end{array}$} & \multirow{2}{*}{$\begin{array}{l}C F \\
\text { titre }\end{array}$} & \multicolumn{3}{|c|}{ Indirect haemagglutination } \\
\hline & & $\begin{array}{l}\text { Negative } \\
(<1 / 10)\end{array}$ & $\begin{array}{l}\text { Positive } \\
(>1 / 10)\end{array}$ & $\begin{array}{l}\text { Non-specific } \\
\text { agglutination }\end{array}$ \\
\hline \multicolumn{5}{|l|}{ Category I } \\
\hline 174 & $<1 / 20$ & 169 & 0 & 5 \\
\hline 64 & $1 / 20$ & 63 & 1 & 0 \\
\hline 79 & $1 / 40$ & 76 & 1 & 2 \\
\hline 18 & $1 / 80$ & 17 & 0 & 1 \\
\hline \multicolumn{5}{|l|}{ Category II } \\
\hline 27 & $1 / 160$ & 14 & 13 & $\mathbf{0}$ \\
\hline 18 & $1 / 320$ & 5 & 12 & 1 \\
\hline 63 & $>1 / 640$ & 4 & 54 & 5 \\
\hline Total 443 & & 348 & 81 & 14 \\
\hline
\end{tabular}

In order to determine whether the IHa test will detect antibody at an earlier stage than CF the results of both tests on sera from patients within category II have been tabulated in relation to the time between onset of symptoms and collection of serum sample (Table 2). Of the 23 sera received up to two weeks after onset, $17 \%$ were negative by IHa: whereas no negatives were found in the 10 sera from patients with illnesses of three weeks' duration. The

Table 2 Complement fixation and indirect haemagglutination titres produced at varying times after infection with M. pneumoniae (category II sera)

\begin{tabular}{|c|c|c|c|c|c|c|c|}
\hline \multirow{2}{*}{$\begin{array}{l}\text { Weeks } \\
\text { after onset }\end{array}$} & \multirow{2}{*}{$\begin{array}{l}\text { No. of } \\
\text { sera tested }\end{array}$} & \multicolumn{3}{|c|}{ Complement fixation titre } & \multicolumn{3}{|c|}{ Indirect haemagglutination } \\
\hline & & $1 / 160$ & $1 / 320$ & $>1 / 640$ & $\begin{array}{l}\text { Negative } \\
(<10)\end{array}$ & $\begin{array}{l}\text { Positive } \\
(>10)\end{array}$ & Non-specific agglutination \\
\hline $\begin{array}{c}<2 \\
3 \\
4 \\
>5 \\
\text { Unknown }\end{array}$ & $\begin{array}{l}23 \\
10 \\
11 \\
18 \\
46\end{array}$ & $\begin{array}{r}8 \\
0 \\
0 \\
3 \\
16\end{array}$ & $\begin{array}{l}3 \\
1 \\
3 \\
6 \\
5\end{array}$ & $\begin{array}{r}12 \\
9 \\
8 \\
9 \\
25\end{array}$ & $\begin{array}{r}4 \\
0 \\
2 \\
4 \\
13\end{array}$ & $\begin{array}{r}18 \\
8 \\
7 \\
13 \\
33\end{array}$ & $\begin{array}{l}1 \\
2 \\
2 \\
1 \\
0\end{array}$ \\
\hline
\end{tabular}


number of sera negative by IHa increased four and five weeks after onset, the most sera negative by this test being observed when no information was available concerning the onset of symptoms. The majority of sera $(90 \%)$ tested three weeks after the onset of symptoms showed CF titres of $1 / 640$ or above.

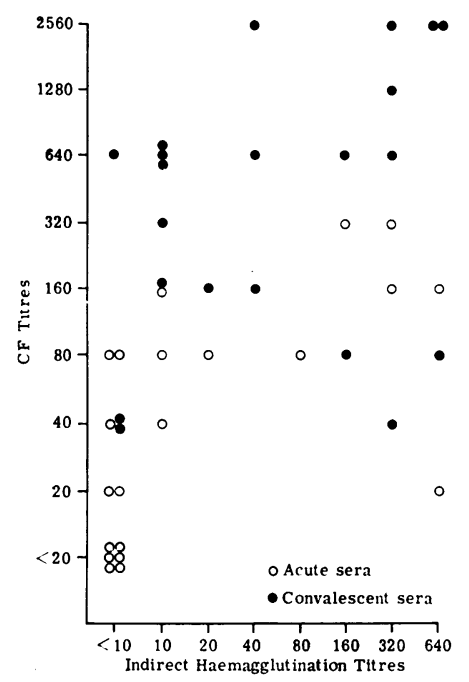

Figure Comparison of $C F$ and indirect haemagglutination titres on acute and convalescent sera from patients with M. pneumoniae infections (category III sera).

The results of 21 of the paired sera in category III are presented in the Figure. Sera from two patients exhibited non-specific agglutination and were therefore excluded. Sera from three patients failed to react in the IHa test. In two patients in whom the CF rise was minimal the sera had been collected several weeks after infection (4 and 6 weeks and 7 and 9 weeks respectively). The actual titres overall were much higher by CF than by the IHa test. In nine cases the IHa test showed fourfold rising titres: in three twofold rises were obtained, in three there were declining IHa levels, and in three other cases there were no changes in IHa titres. These results, in part, demonstrate that the two tests do not measure identical proportions of IgM and IgG antibody. Five of the 'acute' sera had detectable IHa titres when CF titres were not raised beyond $1 / 80$, suggesting that IHa may be more sensitive than CF in the early detection of infection.

\section{Discussion}

The Fujizoki IHa test is a simple one requiring only a small volume of serum which does not have to be inactivated. It is rapid, the results being read after incubation for one hour. For these reasons the test is an improvement over CF. The only other specific serological test that compares with $\mathrm{IHa}$, with respect to simplicity and speed, is counterimmunoelectrophoresis (CIEOP) (Menonna et al., 1977). Preliminary experiments (Taylor, unpublished results) indicate that CIEOP, unlike IHa, is able to detect only cases in which CF titres are $1 / 160$ or greater even where the 'acute' serum shows $\mathrm{CF}$ and IHa titres of $1 / 80$. CIEOP is therefore considered to have little advantage in the examination of specimens collected shortly after the onset of illness. One of the minor disadvantages of $\mathrm{IHa}$ is the presence of non-specific agglutinins in certain sera. In the present study these could not be removed with chicken erythroyctes; other methods of treatment, including differential titration of sera with unsensitised and sensitised cells together with prior treatment of sera with 2-mercaptoethanol (Roberts and Hobbs, 1977), are currently being investigated. However, this problem is not common since only $3.7 \%$ of al the sera tested contained non-specific agglutinins. The incidence was much lower in fresh sera or in those that had been stored at $-30^{\circ} \mathrm{C}$ for only a few weeks.

A titre of $1 / 10$ or greater in the IHa test has, in this study, been taken as evidence of recent exposure. Higher baseline titres have been used by Lind (1968), who regarded titres of $1 / 160$ or more as significant, and Ghyka et al. (1977) used 1/128 as their borderline for significance. The low positive titre with the Fujizoki kit is, however, beneficial since it enables a qualitative screening test at a dilution which requires minimal titration.

The sera of two patients within category I produced positive IHa titres in the absence of raised CF levels which may indicate early infection with $M$. pneumoniae. This suggestion is supported by titres of 'acute' sera from five patients in category III which gave similar results. In some cases, therefore, the IHa test has been shown to be more sensitive than CF in confirming 'acute' infections and single sera may suffice for diagnosis.

The results suggest that IHa is specific for $M$. pneumoniae infections, firstly by the absence of IHa titres in those sera in category I which had raised CF titres to respiratory viruses, $C$. psittaci and $C$. burneti, and secondly by the general correlation between CF and $\mathrm{IHa}$ in sera from category II and III patients. The higher the CF titre with the single sera in category II, the greater were the number of positive IHa titres. A possible explanation is that CF titres may in some instances remain at a level of $1 / 160$ long after recovery from infection. Consequently some of the CF titres of $1 / 160$ may 
represent past rather than current infection. The IHa like the CF test seems to be most sensitive between two and three weeks after the onset of symptoms. This finding is in agreement with the results of Clyde and Denny (1967). TaylorRobinson et al. (1966) suggested that IHa may detect antibody to $M$. pneumoniae at a much earlier stage than other methods which they tested including CF.

Towards the latter part of the study sera from patients with 'atypical pneumonia' were examined by IHa testing on the same day that they were received in the laboratory. This resulted in 10 cases being reported immediately as containing antibodies to $M$. pneumoniae detected by IHa, allowing chemotherapy to begin promptly. All of these 10 cases were subsequently confirmed by raised $\mathrm{CF}$ levels but two had low initial CF levels and required convalescent sera to show fourfold rises in titre.

Since a few sera with raised or fourfold rising CF titres were negative by $\mathrm{IHa}$ it is suggested that all sera giving negative IHa results should be retested by $\mathrm{CF}$ before being reported.

In conclusion, the Fujizoki indirect haemagglutination kit is a simple, rapid, and relatively sensitive test for the detection of antibodies to M.pneumoniae. It is a valuable aid to early diagnosis and can be recommended for adoption routinely in combination with CF tests in a diagnostic clinical service.

I thank my scientific colleagues in the Department of Pathology for their assistance and advice and my clinical colleagues for their patience and enthusiasm. I am also grateful to Diamed Diagnostics Limited for the supply of the Fujizoki kits.

\section{References}

Bradstreet, C. M. P., and Taylor, C. E. D. (1962). Technique of complement-fixation test applicable to the diagnosis of virus disease. Monthly Bulletin of the
Ministry of Health and the Public Health Laboratory Service, 21, 96-104.

Brunner, H., Horswood, R. L., and Chanock, R. M. (1973). More sensitive methods for detection of antibody to Mycoplasma pneumoniae. Journal of Infectious Diseases, 127, 852-855.

Clyde, W. A., Jr., and Denny, F. W. (1967). Mycoplasma infections in childhood. Pediatrics, 40, 669-684.

Dowdle, W. R., and Robinson, R. Q. (1964). An indirect haemagglutination test for diagnosis of Mycoplasma pneumoniae infections. Proceedings of the Society of Experimental Biology and Medicine, 116, 947-950.

Ghyka, G. R., Stoian, N., Sorodoc, G., Peiulescu, P., Osman, J., and Puca, D. (1977). An antigen for the diagnosis of $M$. pneumoniae infections by passive haemagglutination. Virologie, 28, 111-115.

Lind, K. (1968). An indirect haemagglutination test for serum antibodies against Mycoplasma pneumoniae using formalinised, tanned sheep erythrocytes. Acta Pathologica Microbiologica Scandinavica, 73, 459-472.

Menonna, J., Chmel, H., Menegus, M., Dowling, P., and Cook, S. (1977). Precipitating antibodies in mycoplasma infection. Journal of Clinical Microbiology, 5, 610-612.

Roberts, P. C., and Hobbs, S. J. (1977). Evaluation of a new test system for rubella haemagglutination inhibiting antibodies. Journal of Clinical Pathology, 30, 1011-1014.

Skaug, K., Eng, J., Orstavik, I., and Haugh, K. W. (1976). The diagnostic value of determination of IgM antibodies against Mycoplasma pneumoniae by the indirect immunofluorescent antibody test. Acta Pathologica Microbiologica Scandinavica, 84B, 170-176.

Taylor-Robinson, D., Soběslavský, O., Jensen, K. E., Senterfit, L. B., and Chanock, R. M. (1966). Serologic response to Mycoplasma pneumoniae infection. 1. Evaluation of immunofluorescencs, complement fixation, indirect hemagglutination, and tetrazolium reduction inhibition tests for the diagnosis of infection. American Journal of Epidemiology, 83, 287-298.

Requests for reprints to: P. Taylor, Department of Pathology, Brompton Hospital, Fulham Road, London SW3 6HP, UK. 